\title{
NLRP3 played a role in Trichinella spiralis-triggered Th2 and regulatory T cells response
}

\author{
Xuemin Jin ${ }^{1 \dagger}$, Xue Bai ${ }^{1 \dagger}$, Yong Yang ${ }^{1 \dagger}$, Jing Ding ${ }^{1}$, Haining Shi ${ }^{2}$, Baoquan Fu ${ }^{3}$, Pascal Boireau ${ }^{4}$, Mingyuan Liu ${ }^{1,5^{*}}$ \\ and Xiaolei Liu ${ }^{1 *}(\mathbb{B}$
}

\begin{abstract}
Trichinella spiralis maintains chronic infections within its host. Muscle larvae excretory-secretory products (MLES) typically induce parasite-specific immune responses such as the Th2 response and regulatory $T$ cells (Tregs) by modulating dendritic cell (DC) phenotype via the recognition of pattern recognition receptors (PRRs), such as Nod-like receptors (NLRs). We aimed to investigate the role of NLRP3 in T. spiralis-triggered immune response. We found that larvae burden was increased in NLRP3 ${ }^{-/}$mice compared to wild type (WT) mice. Administration of MLES induced higher levels of IL-4, IL-10, TGF- $\beta$ and population of Tregs in WT mice than in NLRP3 ${ }^{-1-}$ mice. In vitro, we showed that increased expression of CD40 on the surface of MLES-treated DCs was inhibited after NLRP3 knockout. Increased production of IL-1 $\beta$, IL-18, IL-10 and TGF- $\beta$, but not IL-12p70, was significantly diminished in the absence of NLRP3. Furthermore, our results demonstrated that MLES-treated DCs induced higher levels of IL-4, IL-10 and TGF- $\beta$ and populations of Tregs in vitro. These inductions were abolished by NLRP3 deficiency in DCs, suggesting that NLRP3 in MLES-treated DCs plays a role in promoting the Th2 and Treg response. Taken together, we identified for the first time the involvement of NLRP3 in host defences against T. spiralis.
\end{abstract}

Keywords: Trichinella spiralis, excretory-secretory products, dendritic cell, NLRP3, Th2, Treg

\section{Introduction}

Parasitic diseases are a serious global health concern. Trichinellosis, caused by Trichinella spiralis, is one of the most prevalent neglected tropical diseases worldwide, and establishes chronic infection in a wide range of wild and domestic animals and human beings [1]. T. spiralis infection induces strong $\mathrm{T}$ helper 2 (Th2) immune response [2], which contributes equally to host defence against T. spiralis [3]. And Th2 cytokines production is regulated by regulatory $\mathrm{T}$ cells (Tregs) [4].

\footnotetext{
*Correspondence: liumy36@163.com; liuxlei@163.com

${ }^{\dagger}$ Xuemin Jin, Xue Bai and Yong Yang contributed equally to the work

${ }^{1}$ Key Laboratory of Zoonosis Research, Ministry of Education,

Institute of Zoonosis, College of Veterinary Medicine, Jilin University, Changchun 130062, China

Full list of author information is available at the end of the article
}

Parasite antigens have the potential to induce Th2 and Treg responses via dendritic cells (DCs). Indeed, DCs have numerous pattern recognition receptors (PRRs), such as Toll-like receptors (TLRs) or nucleotide-binding oligomerization domain (NOD)-like receptors (NLRs) [5]. T. spiralis muscle larvae excretory-secretory products (MLESs) enable the parasite to survive in the host by interacting with host immune cells and inducing an immune response [6]. T. spiralis MLESs direct the immunological balance away from Th1 cells towards Th2 cells and Tregs by modulating the DC phenotype via toll-like receptors (TLR) 2 and 4 [7]. NLRs signals are provided by TLR engagement that leads to the expression of inflammasome components [5]. TLR such as TLR4 accelerates the production of IL- 1 family cytokines dependent on NLRs [8]. We therefore 
hypothesized that NLRs may play a role in modulating the function of T. spiralis MLESs-treated DCs.

The NLRP3 (NLR family, pyrin domain containing 3) inflammasome is composed of the protein NLRP3, the bipartite adaptor protein ASC (apoptosis-associated speck-like protein containing a CARD), and Caspase-1 and form an important arm of the innate immune system [9]. NLRP3 inflammasome complexes are the most intensively studied and are activated by a broad range of stimuli [10]. Interestingly, accumulating evidence indicates that NLRP3 activation is essential for the control of different parasitic infections. Activation of the NLRP3 inflammasome reduces Toxoplasma gondii infection load [11] and is critical for host resistance to diverse Leishmania species [12]. Inflammasomes are increasingly implicated in regulating immunity, but the relationship between their activation and the function of DCs remains largely unknown. It is still unclear whether NLRP3 in DCs is involved in the T. spiralisinduced immune response.

Here, we demonstrated that mice lacking NLRP3 but not ASC or Caspase-1/11 displayed significantly increased larval burdens. We therefore explored the role of NLRP3 in the immune response induced by T. spiralis infection. We first revealed that NLRP3 in DCs played a role in the induction of Th2 and Treg responses by MLES in vivo and in vitro via modulating DCs phenotype.

\section{Materials and methods \\ Ethics statement}

C57BL/6J wild-type (WT) mice (female, 4-6 weeks old) were purchased from the Norman Bethune University of Medical Science (NBUMS), China. Female Wistar rats were purchased from the Experimental Animal Centre of College of Basic Medical Sciences, Jilin University (Changchun, China). C57BL/6J NLRP3 ${ }^{-1-}$, Caspase $1 / 11^{-1-}$, and $\mathrm{ASC}^{-1-}$ mice were kindly provided by $\mathrm{Dr}$. Feng Shao. OT-II ovalbumin (OVA)-specific T-cell receptor (TCR) transgenic mice (on C57BL/6 background) were purchased from the Nanjing University Model Animal Research Centre (Nanjing, China). All animals were maintained on standard rodent chow with water supplied ad libitum under a $12 \mathrm{~h} / 12 \mathrm{~h}$ light/dark cycle during the experimental period. All animal experiments followed the regulations on animal welfare and Public Health Service recommendations in China. All mice were handled strictly in accordance with the Animal Ethics Procedures and Guidelines of the People's Republic of China. The protocol was approved by the Institutional Animal Care and Use Committee of Jilin University (protocol\# 20170318).

\section{Parasites and preparation of MLES}

The T. spiralis isolate (ISS534) was obtained from a naturally infected domestic pig in Henan Province in China. Briefly, Wistar rats were orally infected with 3000 infective larvae, and $T$. spiralis muscle larvae were recovered at 35 days post infection (dpi) via artificial digestion with pepsin- $\mathrm{HCl}$ (1\% pepsin and $1 \%$ $\mathrm{HCl}$ at $37^{\circ} \mathrm{C}$ for $2 \mathrm{~h}$ ) [13]. All T. spiralis muscle larvae were washed three times in saline solution and incubated separately in prewarmed serum-free RPMI 1640 medium containing $2 \mathrm{mM}$ L-glutamine, $100 \mathrm{U} / \mathrm{mL}$ penicillin, and $100 \mu \mathrm{g} / \mathrm{mL}$ streptomycin at $37{ }^{\circ} \mathrm{C}$ under $5 \%$ atmospheric $\mathrm{CO}_{2}$ for $24 \mathrm{~h}$. After centrifugation, the supernatant containing ES products was dialyzed and concentrated [14]. According to the manufacturer's instructions, the endotoxin was removed from the protein by using the ToxOut ${ }^{\mathrm{TM}}$ High Capacity Endotoxin Removal kit (Biovision, USA). There was about approximately $0.132 \mathrm{EU} / \mathrm{mL}$ residual endotoxin existing in MLES, approximately equivalent to $20 \mathrm{pg} / \mathrm{mg}$ endotoxin [15]. The protein concentration was determined by a Pierce bicinchoninic acid protein assay kit (Thermo Scientific, Rockford, IL). We made three different preparations of ES products from muscle larvae of $T$. spiralis to perform several independent experiments. One representative experiment is shown here.

\section{Larvae burden assessments}

WT and NLRP3 ${ }^{-1-}$ mice were infected with 300 muscle larvae (ML). MLs were recovered and counted at $35 \mathrm{dpi}$ as previously described [16]. Briefly, the muscle tissues of infected mice were cut into pieces and digested by pepsin hydrochloric digestive fluid. The MLs were collected by washing three times in water with sedimentation and were counted with gelatine.

\section{Detection of MLES-induced immune response}

WT and $\mathrm{NLRP}^{-1-}$ mice were injected intraperitoneally (i.p.) with phosphate-buffered saline (PBS) or MLES $(100 \mu \mathrm{g})$ twice at 7 days intervals. Spleen cells were isolated 7 days after second injection. Spleen cells were modulated to $1 \times 10^{6}$ cells $/ \mathrm{mL}$ in complete RPMI-1640 with $10 \%$ fetal bovine serum (FBS), penicillin $(100 \mathrm{U} / \mathrm{mL})$ and streptomycin $(100 \mu \mathrm{g} / \mathrm{mL})$ and stimulated with MLES at a concentration of $50 \mu \mathrm{g} / \mathrm{mL}$ at $37{ }^{\circ} \mathrm{C}$ for $72 \mathrm{~h}$ in an incubator containing $5 \% \mathrm{CO}_{2}$. The supernatants of spleen cells were harvested for detecting cytokines (IFN- $\gamma$, IL-4, IL-10 and TGF- $\beta$ ) production by ELISA (R\&D Systems). The cells were resuspended in PBS for determining Tregs population by flow cytometry. 


\section{Bone marrow-derived dendritic cell (BMDC) isolation, culture, and stimulation}

Bone marrow-dendritic cells (BMDCs) were generated from mouse bone marrow cells as previously described [17]. Briefly, bone marrow cells were obtained from WT and NLRP3 ${ }^{-1-}$ mice and cultured in RPMI 1640 medium containing $20 \mathrm{ng} / \mathrm{mL}$ recombinant GM-CSF, $20 \mathrm{ng} / \mathrm{mL}$ IL-4 (Sigma-Aldrich) and $10 \% \mathrm{FBS}$ at $37{ }^{\circ} \mathrm{C}$ and $5 \% \mathrm{CO}_{2}$. Immature DCs were enriched by positive selection with anti-CD11c magnetic beads (Miltenyi Biotec) according to the manufacturer's instructions. DCs were harvested on day 7 for further experiments. To explore NLRP3 activation in MLES-treated DCs, the DCs were treated with MLES $(50 \mu \mathrm{g} / \mathrm{mL})$ in vitro for $24 \mathrm{~h}$. Immature DCs were stimulated with sterile phosphate-buffered saline (PBS) as a control. Cells and cell culture supernatants were collected and stored at $-80{ }^{\circ} \mathrm{C}$. Cytokines (IL-1 $\beta$, IL-18, IL12 p70, IL-10 and TGF- $\beta$ ) levels in the supernatant were quantified by ELISA (R\&D Systems). The stimulated DCs were stained with a PE-conjugated monoclonal antibody $(\mathrm{mAb})$ to $\mathrm{CD} 11 \mathrm{c}$ and APC-conjugated mAbs to CD40, CD80 or CD86 (Biolegend, USA). The cells were analysed by using a BD FACSCalibur Flow Cytometer and FlowJo software (Tree star Inc, Ashland, OR) [18].

\section{Co-culture of BMDCs with $\mathrm{CD}^{+}{ }^{+} \mathrm{T}$ cells}

$\mathrm{CD}^{+} \mathrm{T}$ cells from OT-II mice were purified from spleen cells by magnetic sorting using anti-CD4 magnetic beads (Miltenyi Biotec, Auburn, CA) as previously described [18]. The purified $\mathrm{CD}^{+} \mathrm{T}$ cells had $>90 \%$ purity. DCs $\left(1 \times 10^{5} /\right.$ well $)$ were first treated with PBS or MLESs $(50 \mu \mathrm{g} / \mathrm{mL})$ for $24 \mathrm{~h}$. DCs were washed three times with sterile PBS and resuspended in RPMI 1640 medium. DCs treated with PBS or MLESs and CD4 ${ }^{+} \mathrm{T}$ cells $\left(1 \times 10^{6} \%\right.$ well) were cocultured with OVA $(1 \mathrm{mg} / \mathrm{mL})$ for $72 \mathrm{~h}$. During the final $18 \mathrm{~h}, 2.5 \mu \mathrm{g} / \mathrm{mL}$ concanavalin-A (Con-A) (Sigma-Aldrich, St. Louis, MO, USA) was added. Samples were analysed using a BD FACSCalibur flow cytometer and FlowJo software (Tree star Inc, Ashland, OR). The supernatants of $\mathrm{DC}$ and $\mathrm{CD}^{+}{ }^{+} \mathrm{T}$ cell cocultures were harvested for cytokine (IFN- $\gamma$, IL-4, IL-10 and TGF- $\beta$ ) analysis by ELISA kits (R\&D Systems).

For $\mathrm{T}$ helper-related cytokines expression, after coculture of DCs $\left(1 \times 10^{5} /\right.$ well $)$ and CD $4^{+}$T cells $\left(1 \times 10^{6} /\right.$ well $)$ for $72 \mathrm{~h}$ with OVA $(1 \mathrm{mg} / \mathrm{mL})$, then cells were incubated with $10 \mathrm{mg} / \mathrm{mL}$ Brefeldin A (eBioscience, San Diego, CA, USA), $50 \mathrm{ng} / \mathrm{mL}$ phorbol 12-myristate 13-acetate (PMA) (eBioscience, San Diego, CA, USA) and $750 \mathrm{ng} / \mathrm{mL}$ Ionomycin (eBioscience, San Diego, CA, USA) for $6 \mathrm{~h}$ at $37^{\circ} \mathrm{C}$. Cells were stained for surface markers (FITC-antiCD4 antibodies, BD Biosciences) for $35 \mathrm{~min}$ at $4{ }^{\circ} \mathrm{C}$ in the dark. These cells were fixed, permeabilized using a FIX/
PERM set (Biolegend) and blocked in 5\% rat serum for $10 \mathrm{~min}$ at room temperature prior to intracellular staining with APC-conjugated mAbs to IFN- $\gamma$, IL-4, IL-10 or TGF- $\beta$. In addition, the induction of Tregs by MLEStreated DCs was measured. $\mathrm{CD}^{+}{ }^{+}$cells were first preincubated with Fc Blocker (anti-mouse CD16/CD32, BD Biosciences, USA) for 15 min to reduce nonspecific binding of labelled antibodies, then stained with APC-labelled anti-CD25, fixed and permeabilized using a FIX/PERM set (BD Biosciences, USA). The cells were then incubated in CD16/CD32 antibody prior to intracellular staining for Percp Cy5.5-labelled anti-Foxp3. For Foxp3 staining, the cells were fixed and permeabilized using the Foxp3 transcription factor staining buffer kit (eBioscience) according to the manufacturer's instructions. Appropriately labelled isotype-matched antibodies were used as controls. Samples were analysed by using a BD FACSCalibur flow cytometer and FlowJo software (Tree star Inc, Ashland, OR).

\section{Statistical analysis}

All results are expressed as the mean \pm SD. Statistical analysis was performed using GraphPad Prism 5 for Windows. Two experimental groups were compared using Student's t-test for nonparametric data. Three or more groups were compared through one-way analysis of variance (ANOVA) with Tukey's multiple comparison test or Dunnett's multiple comparison test as indicated. Two-way ANOVA with a Bonferroni test for multiple comparisons was used to compare the data. P values are expressed as *p $<0.05$, ** $\mathrm{p}<0.01$ and $* * * \mathrm{p}<0.001$.

\section{Result}

\section{T. spiralis larval burden increased in mice lacking NLRP3} but not Caspase $1 / 11$ or ASC

To determine whether NLRP3 inflammasome complexes, including NLRP3, Caspase 1 and ASC, played a role in the interaction between $T$. spiralis and the host, muscle larvae were recovered from WT, NLRP3 ${ }^{-/-}$, Caspase $1 / 11^{-/-}$, and $\mathrm{ASC}^{-/-}$mice infected with T. spiralis and quantified. As shown in Figure 1, NLRP3 ${ }^{-1-}$ mice had a significantly higher larval burdens at $35 \mathrm{dpi}$ compared with those of WT mice. Larval burden in Caspase $1 / 11^{-/-}$and $\mathrm{ASC}^{-/-}$mice did not significantly differ from those of WT mice. These results indicate that NLRP3 participates in the host-parasite interaction.

\section{NLRP3 played a role in $T$. spiralis -triggered immune response in vivo}

To confirm the role of NLRP3 in the induction of immune response by $T$. spiralis, we measured cytokine production and Tregs population in WT and NLRP3 ${ }^{-/-}$ mice injected with MLES. Our results demonstrated that 


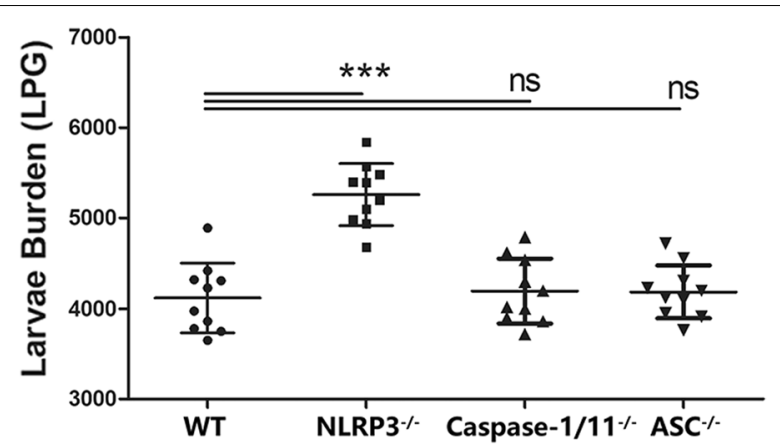

Figure 1 T. spiralis larval burden increased in mice lacking NLRP3 but not Caspase 1/11 or ASC. WT and NLRP3 ${ }^{-1-}$ mice were infected with $300 \mathrm{ML}$. Muscle larvae were recovered at $35 \mathrm{dpi}$ from WT and NLRP3 ${ }^{-1-}$ mice and calculated. The symbols represent individual animals, and horizontal lines indicate the medians. The data shown are representative of three independent experiments. ${ }^{*} p<0.05,{ }^{* *} p<0.01$ and ${ }^{* * *} p<0.001$ vs WT mice $(n=10)$ as indicated by the line (Dunnett's multiple comparison following ANOVA). No significance is marked as ns.

MLES triggered the higher production of IL-4, IL-10 and TGF- $\beta$ in WT mice than in NLRP3 ${ }^{-1-}$ mice (Figure $2 \mathrm{~A}$ ). The level of IFN- $\gamma$ was not significantly different among all groups. And MLES increased the percentage of $\mathrm{CD} 4^{+}$ CD $25^{+}$Foxp $^{+} \mathrm{T}$ cells compared to PBS in WT mice, whereas $\mathrm{NLRP}^{-1-}$ mice treated with MLES exhibited lower Tregs populations compared to WT mice (Figure $2 \mathrm{~B}, \mathrm{C})$.

\section{NLRP3 played a role in modulating the phenotype of MLES-treated DCs in vitro}

We showed that costimulatory molecules on the surface of DCs were upregulated by MLESs compared to those in the PBS group. NLRP3 ${ }^{-1}$ PBS-treated DCs displayed increased levels of CD40, CD80 and CD86 compared to those of WT DCs, whereas there is no significant difference. Notably, the percentage of $\mathrm{CD} 11 \mathrm{c}^{+} \mathrm{CD} 40^{+} \mathrm{DCs}$ from $\mathrm{NLRP3}^{-1-}$ mice treated with MLES was significantly inhibited compared to those of WT DCs treated with MLES (Figure 3). We demonstrated that MLESs promoted IL-1 $\beta$, IL-18, IL-10 and TGF- $\beta$ production compared to PBS group. These increases in production were diminished in DCs isolated from mice lacking NLRP3. However, no significant difference was observed in the level of IL-12p70 among the groups (Figure 4).

\section{NLRP3 in DCs played a role in the differentiation of Th2 cells and Treg responses in vitro}

MLESs lead to the production of Th2 cells and regulatory cytokines under the influence of DCs [19]. To investigate the role of NLRP3 in T cell differentiation by MLEStreated DCs, naïve $\mathrm{CD} 4^{+} \mathrm{T}$ cells were cocultured with
WT or NLRP3 DCs. ELISA results showed that IFN- $\gamma$ production induced by MLES-treated DCs from two mice failed to show a significant difference. WT MLES-treated DCs significantly increased IL-4, IL-10 and TGF- $\beta$ secretion, which was significantly diminished when $\mathrm{CD} 4^{+}$ $\mathrm{T}$ cells were cocultured with $\mathrm{NLRP}^{-1-}$ DCs (Figure 5). Then the increased capacity of MLES-treated DCs for the induction of regulatory cytokines in $\mathrm{T}$ cells was measured by flow cytometry. MLES-DCs displayed an impaired potential to induce $\mathrm{CD} 4^{+} \mathrm{IL}_{-} 4^{+} \mathrm{T}$ cells, $\mathrm{CD} 4^{+}$ IL- $10^{+}$T cells and CD4 ${ }^{+}$TGF- $\beta^{+}$T cells in the absence of NLRP3 (Figure 6). Furthermore, FACS results showed that the population of $\mathrm{CD} 4^{+} \mathrm{CD} 25^{+} \mathrm{Foxp}^{+} \mathrm{T}$ cells was significantly increased by MLES-treated WT DCs compared to that of the PBS group, whereas NLRP3 ${ }^{-1-}$ DCs induced a lower percentage of Tregs (Figure 7).

\section{Discussion}

NLRs (nucleotide-binding domain leucine-rich-repeatcontaining proteins) are known to be involved in pathogen-host interactions. The NLR family, pyrin domain containing 3 (NLRP3) is the most well-characterized NLRs and is important for immunity to diverse pathogens [20]. The role of NLRP3 in the host response to parasitic infection is just beginning to be understood but is comparatively less studied than that of bacterial or viral pathogens [21]. The NLRP3 have been shown to contribute to immune responses to infection with Trypanosoma cruzi [22], Toxoplasma gondii [23], Paracoccidioides brasiliensis [24], and Leishmania species [25], whereas the role of NLRP3 in the immune response to Trichinella spiralis infection is not yet clear. T. spiralis is a natural pathogen of rodents that establishes a chronic infection and results in impaired Th1 development and an immune bias towards Th2 cells or Tregs $[6,26]$. Th2 and Treg responses are ultimately of critical importance for the survival of both the parasite and the host [27]. Our results demonstrated that $T$. spiralis-triggered Th2 and Treg response was decreased in NLRP3 ${ }^{\prime-}$ mice treated with MLES, indicating that NLRP3 may participate in the development of Th2 and Treg response during T. spiralis infection.

Dendritic cells, as the orchestrators of immune responses, are well equipped to efficiently sense helminth infections in a variety of ways and trigger $\mathrm{T}$ cell responses by modulating DC phenotype and function [28]. In our study, we measured the phenotype of DCs treated with T. spiralis MLES, which can interact with host immune cells and induce an immune response that enables the survival of both the parasite and the host [6]. It has been reported that $T$. spiralis molecules modulate the phenotype of DCs via activation of TLR2 and TLR4 [7, 28], which are needed for NLRP3 activation [21]. There are 

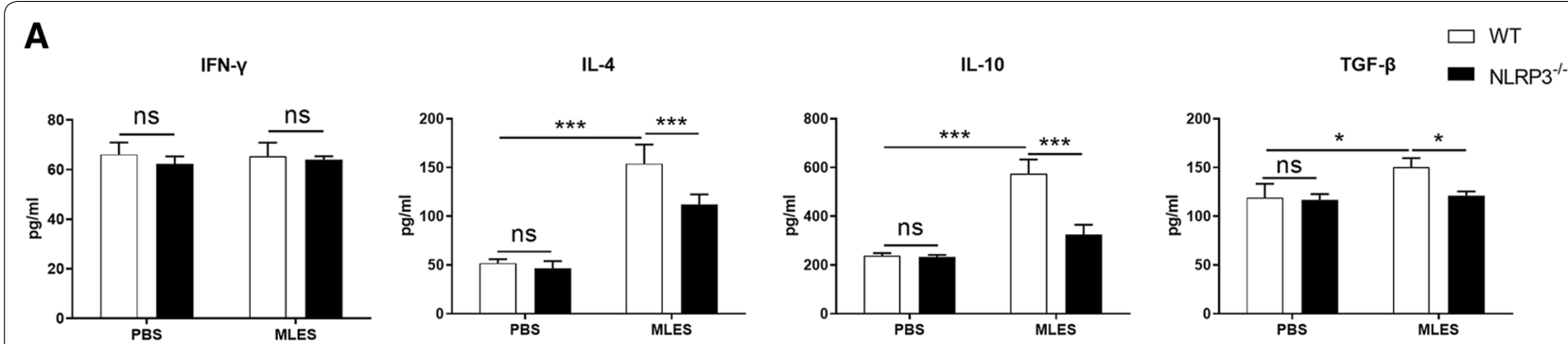

B

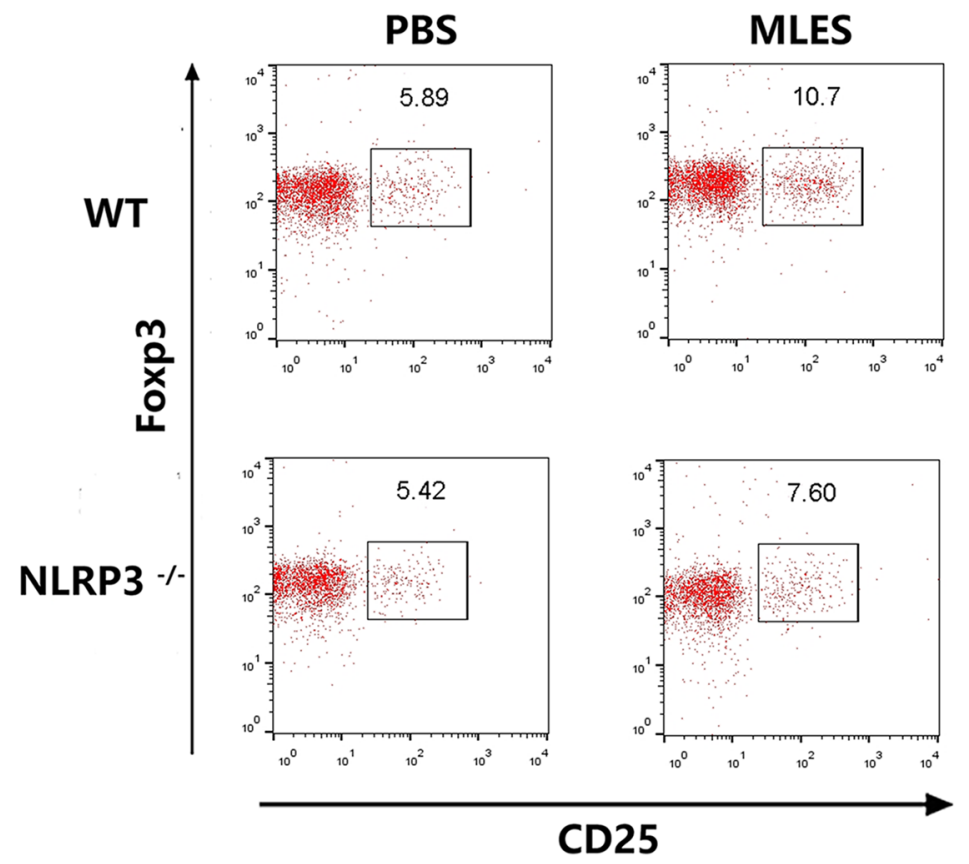

C

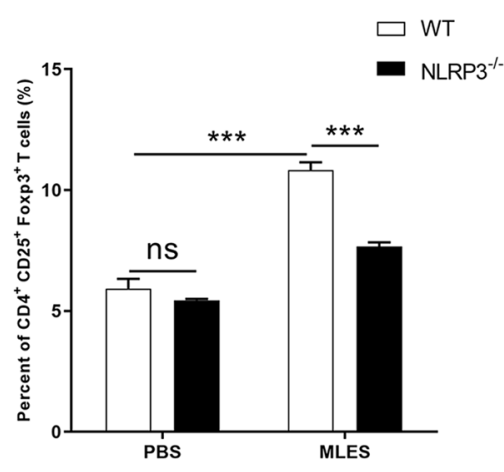

Figure 2 NLRP3 played a role in T. spiralis -triggered immune response in vivo. WT and NLRP3 ${ }^{-1-}$ mice were injected intraperitoneally (i.p.) with phosphate-buffered saline (PBS) or MLES $(100 \mu \mathrm{g})$ twice at 7 days intervals. Spleen cells were isolated 7 days after second injection. A IFN- $\gamma$, IL-4, IL-10 and TGF- $\beta$ production was measured by ELISA. B Treg populations induced by MLES were measured. CD $4^{+} \mathrm{CD} 25^{+}$Foxp $3^{+} \mathrm{T}$ cells were determined by flow cytometry. The data represent the means \pm standard deviations (SD) of each group $(n=6)$ of the results from three individual experiments ${ }^{*} p<0.05,{ }^{* *} p<0.01$, and ${ }^{* * *} p<0.001$ as indicated by the line (one-way ANOVA with Tukey's post-test). These figures are representative of three independent experiments.

other signals, such as $\mathrm{K}+$ efflux, ROS production, and lysosomal damage [21], and additional studies are needed to define the ways that T. spiralis MLESs activate NLRP3. Moreover, the NLRP3 inflammasome is a multiprotein assembly of the NLR-family protein NLRP3, pro-caspase-1, and an apoptosis-associated speck-like protein containing a CARD (ASC) adaptor, which is formed upon activation [25]. We demonstrated that larval burden increased in $\mathrm{NLRP}^{-1-}$ mice but not in Caspase $1 / 11^{-1-}$ and $\mathrm{ASC}^{-1-}$ mice, suggesting that NLRP3 plays a role in the interaction between $T$. spiralis and the host.

We investigated the role of NLRP3 in modulating the DC phenotype. Interestingly, we observed that NLRP3 defects resulted in a reduction in the MLES-induced increased CD40 expression on the surface of DCs. The development of the Th2 response is impaired in the absence of CD40 on DCs [28].However, CD80 and CD86 expression on MLES-treated NLRP3 ${ }^{-1-}$ DCs was enhanced compared to that of WT DCs. In contrast, activation of NLRP3 suppressed the expression of CD80 and CD86 [29]. Parasitic helminths are able to establish a state of immune hypo-responsiveness or tolerance by modulating the phenotype of DCs [30], and deletion of NLRP3 may influence this state. Furthermore, MLESs promoted IL-1 $\beta$, IL-18, IL-10 and TGF- $\beta$ production by WT DCs, while these elevated production levels were attenuated in MLES-treated NLRP3 ${ }^{-1-}$ DCs. NLRP3 is critical for innate immunity and inducing the release 


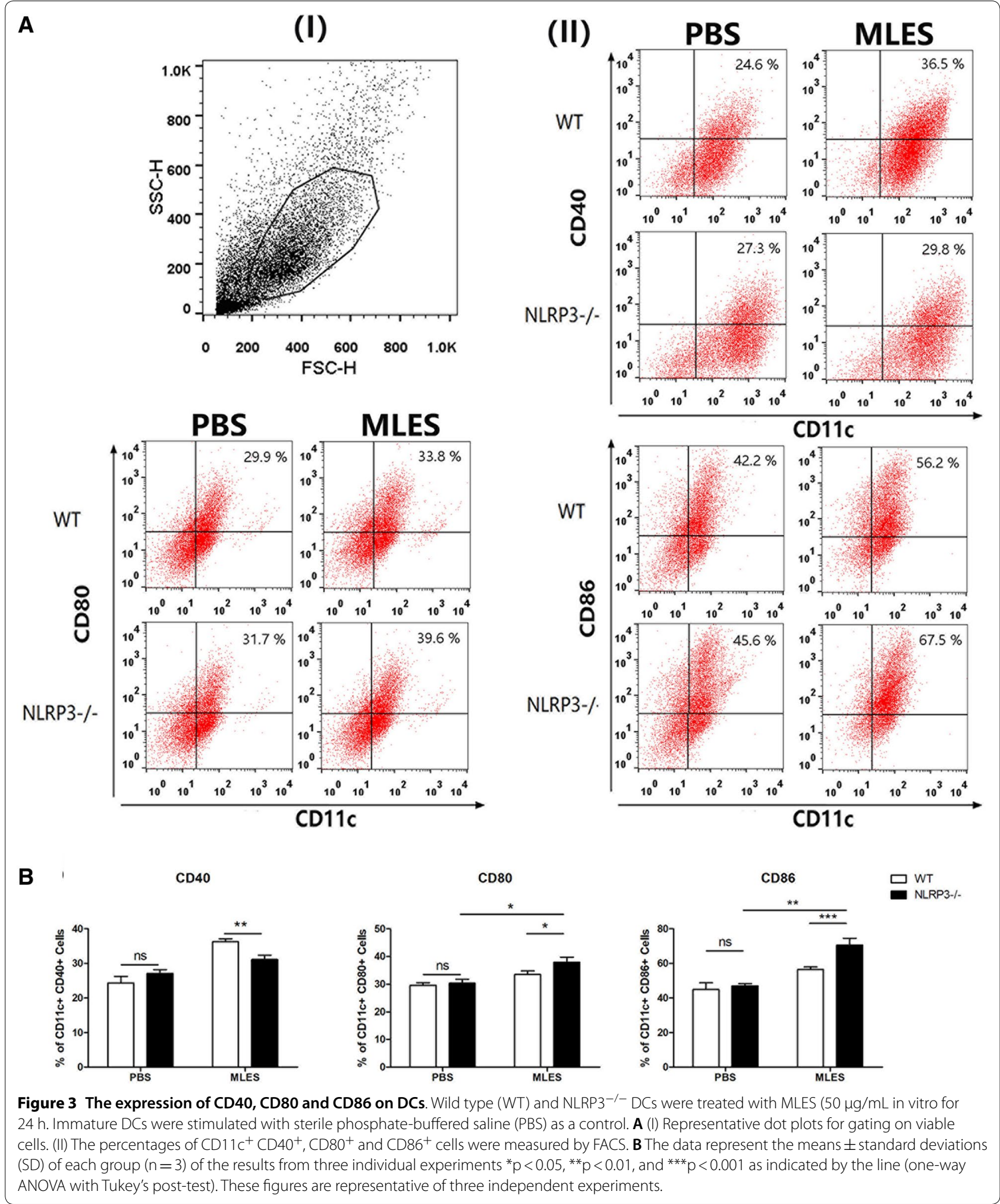



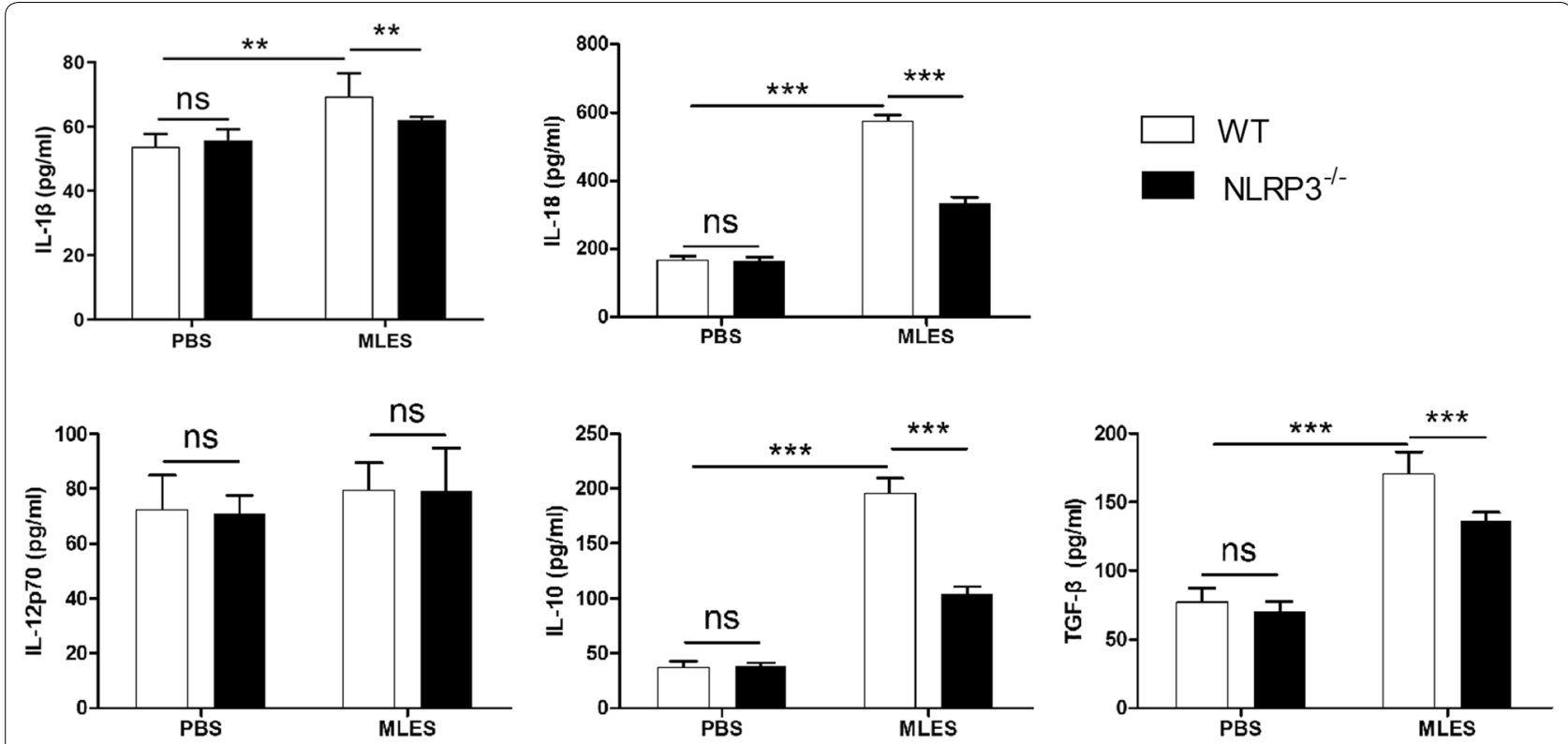

Figure 4 Cytokine production by DCs. Wild type (WT) and NLRP3 ${ }^{-/-}$DCs were treated with PBS or MLES ( $\left.50 \mu \mathrm{g} / \mathrm{mL}\right)$ in vitro for $24 \mathrm{~h}$. Cell culture supernatants were collected. IL-1 $\beta, I L-18, I L-12 p 70, I L-10$ and TGF- $\beta$ production was measured by ELISA. The data are the mean \pm SD of each group $\left(n=3\right.$ from three independent experiments. ${ }^{*} p<0.05$ and ${ }^{* *} p<0.01$ as indicated by the lines.
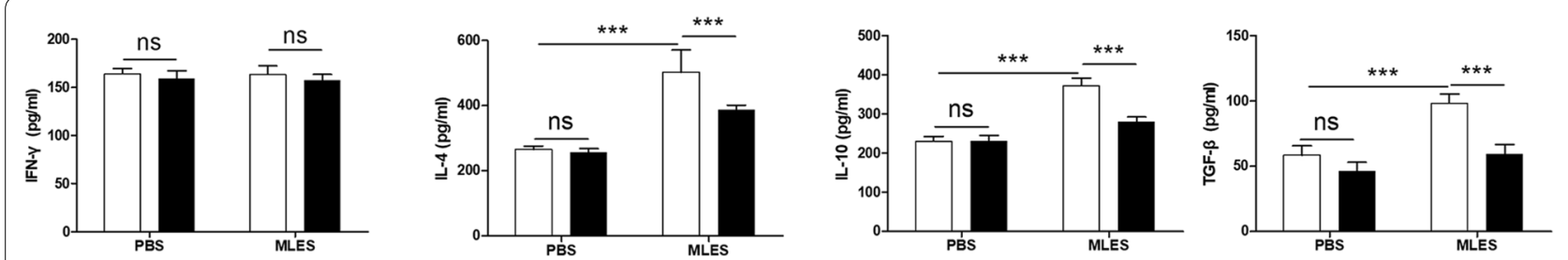

Figure 5 Cytokine production in coculture of DCs and T cells in vitro. DCs treated with PBS or MLESs and CD4 ${ }^{+} \mathrm{T}$ cells $\left(1 \times 10^{6} /\right.$ well) were cocultured with OVA (1 mg/mL) for $72 \mathrm{~h}$. During the final $18 \mathrm{~h}, 2.5 \mu \mathrm{g} / \mathrm{mL}$ concanavalin-A (Con-A) was added. The supernatants of DC and CD4 ${ }^{+} T$ cell cocultures were harvested for cytokine (IFN- - , LL-4, IL-10 and TGF- $\beta$ ) analysis by ELISA. The results are shown as the mean $\pm S D(n=3)$ of three different experiments. ${ }^{*} p<0.05,{ }^{* *} p<0.01$, and ${ }^{* * *} p<0.001$ as indicated by the line (one-way ANOVA with Tukey's post-test).

of IL-1 $\beta$ and IL-18 [31]. NLRP3 inflammasome activation leading to IL-1 $\beta$ production is critical for the induction of a Th2 response [32]. IL-1 $\beta$-deficient mice are susceptible to chronic T. muris infection and that the inability to expel the worms is associated with a defect in the development of a Th2 response, suggesting that the critical role of IL-1 in regulating Th2 response during gastrointestinal nematode infection [33]. IL-18 increases the production of IL-4 and IL-13 by $\mathrm{T}$ cells and enhances the Th2 response [34]. IL-4 and IL-13 levels decrease in $\mathrm{NLRP}^{-/-}$mice during intestinal stage of $T$. spiralis infection [35]. Additionally, NLRP3 inflammasome activation induces secretion of IL-18, which promotes Treg differentiation [36]. And DC-derived IL-18 acts directly on T cells to trigger their conversion to Tregs [37]. It has been reported that activation of NLRP3 leads to increased IL-10 production by DCs [38], and IL-10 has been linked to the induction of Th2 polarization [39]. Lack of NLRP3 impairs the immunomodulatory effect of TGF- $\beta 1$ signalling [40], which is required for Treg differentiation [41]. Taken together, these results indicate that NLRP3 in MLES-treated DCs participates in the Th2 or Treg response. A balanced Th2 and Treg response is ultimately of critical importance for the survival of both the parasite and the host. DC, as the orchestrators of immune responses, are efficiently sense helminth infections in a variety of ways [27].

Coculture of DCs and naïve $\mathrm{CD} 4^{+} \mathrm{T}$ cells demonstrated that the levels of IL-4, IL-10 and TGF- $\beta$ were significantly elevated by MLES-treated WT DCs, suggesting that $\mathrm{CD}^{+} \mathrm{T}$ cells may be polarized to Th2 cells and Tregs. 

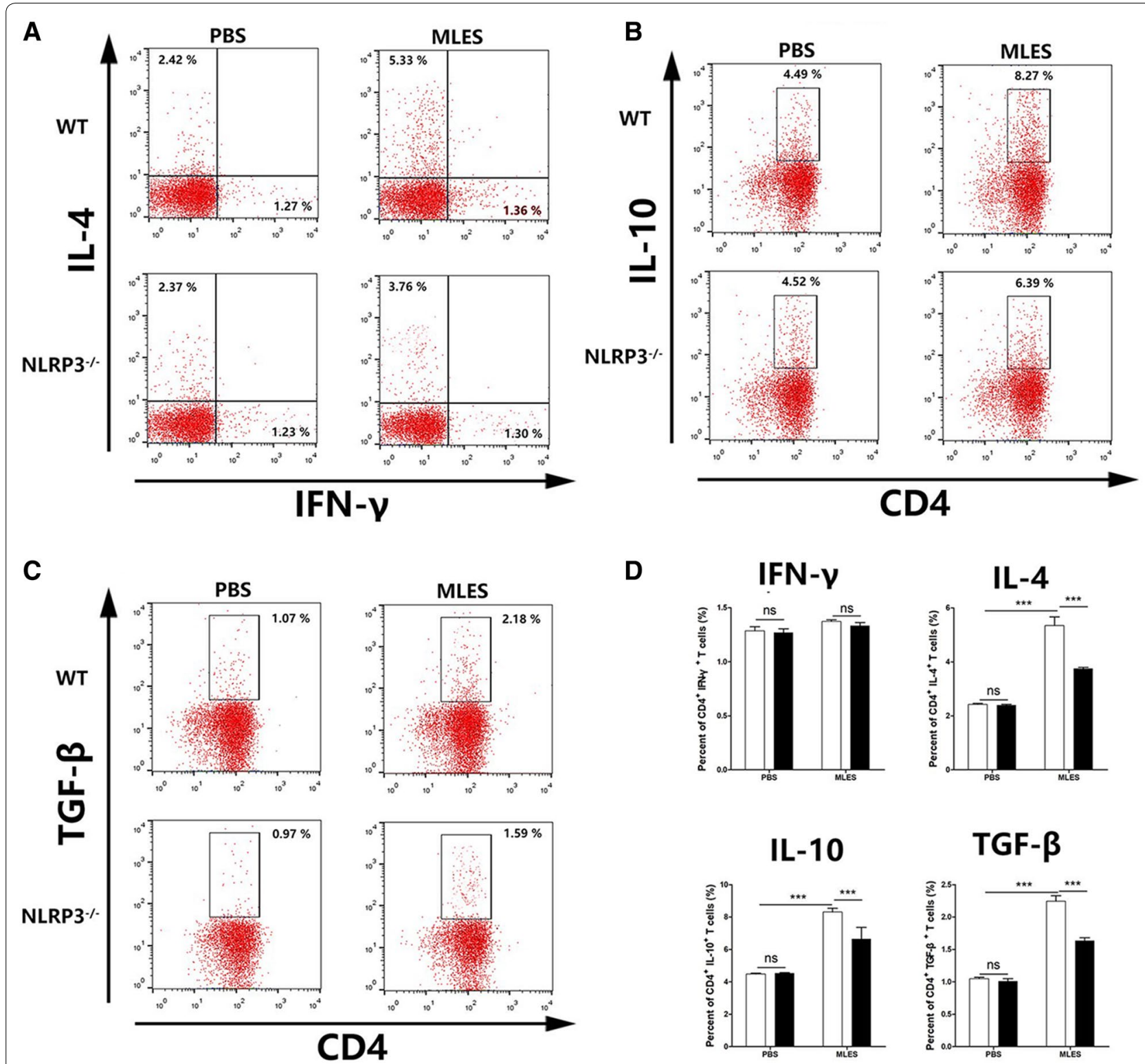

Figure 6 Cytokine levels of CD4 ${ }^{+} \mathrm{T}$ cells by MLES -treated DCs in vitro. For T helper-related cytokines expression, after coculture of DCs $\left(1 \times 10^{5} /\right.$ well $)$ and CD4 $4^{+}$T cells $\left(1 \times 10^{6} /\right.$ well) for $72 \mathrm{~h}$ with OVA $(1 \mathrm{mg} / \mathrm{mL})$, then cells were incubated with $10 \mathrm{mg} / \mathrm{mL}$ Brefeldin A, $50 \mathrm{ng} / \mathrm{mL} \mathrm{phorbol}$ 12-myristate 13 -acetate (PMA) and $750 \mathrm{ng} / \mathrm{mL}$ lonomycin for $6 \mathrm{~h}$ at $37^{\circ} \mathrm{C}$. A Percent of CD4 ${ }^{+} \mathrm{IFN}-\gamma^{+} \mathrm{T}$ cells and CD4+ $4^{+}-4^{+} \mathrm{T}$ cells were shown. B Percent of $\mathrm{CD} 4^{+} \mathrm{IL}-4^{+} \mathrm{T}$ cells was shown. (B) Percent of $\mathrm{CD} 4^{+} \mathrm{IL}-10^{+} \mathrm{T}$ cells was shown. C Percent of CD4 ${ }^{+} \mathrm{TGF}-\beta^{+} \mathrm{T}$ cells was shown. $\mathbf{D}$ Data are shown as the mean $\pm S D$ (three independent experiments) of each group $(n=3) .{ }^{*} p<0.05,{ }^{* *} p<0.01,{ }^{* * *} p<0.001$ as indicated by line (one-way ANOVA with Tukey's posttest). These figures are representative of three independent experiments.

The Th2 response with upregulation of IL-4 induced by $T$. spiralis promotes the development of eosinophils, mastocytosis, mast cell degranulation, and an immunoglobulin $\mathrm{E}(\mathrm{IgE})$ response that is associated with protection against T. spiralis infection [3].Treg response was involved in the anti-inflammatory effects of helminth infection and exist in the ML phase [42]. However, NLRP3 ${ }^{-/-}$DCs treated with MLESs induced reduced IL-4, IL-10 and TGF- $\beta$ secretion in vitro. Consistently, FACS results showed that enhanced Treg populations were also inhibited in MLEStreated DCs lacking NLRP3. The level of IFN- $\gamma$ was not altered, which may be due to the lack of significant changes in the levels of IL-12p70-producing DCs, which results in IFN- $\gamma$-secreting Th1 cell differentiation [43]. Another possible explanation is that Tregs prevent development of the Th1 response [38]. NLRP3 in DCs treated 


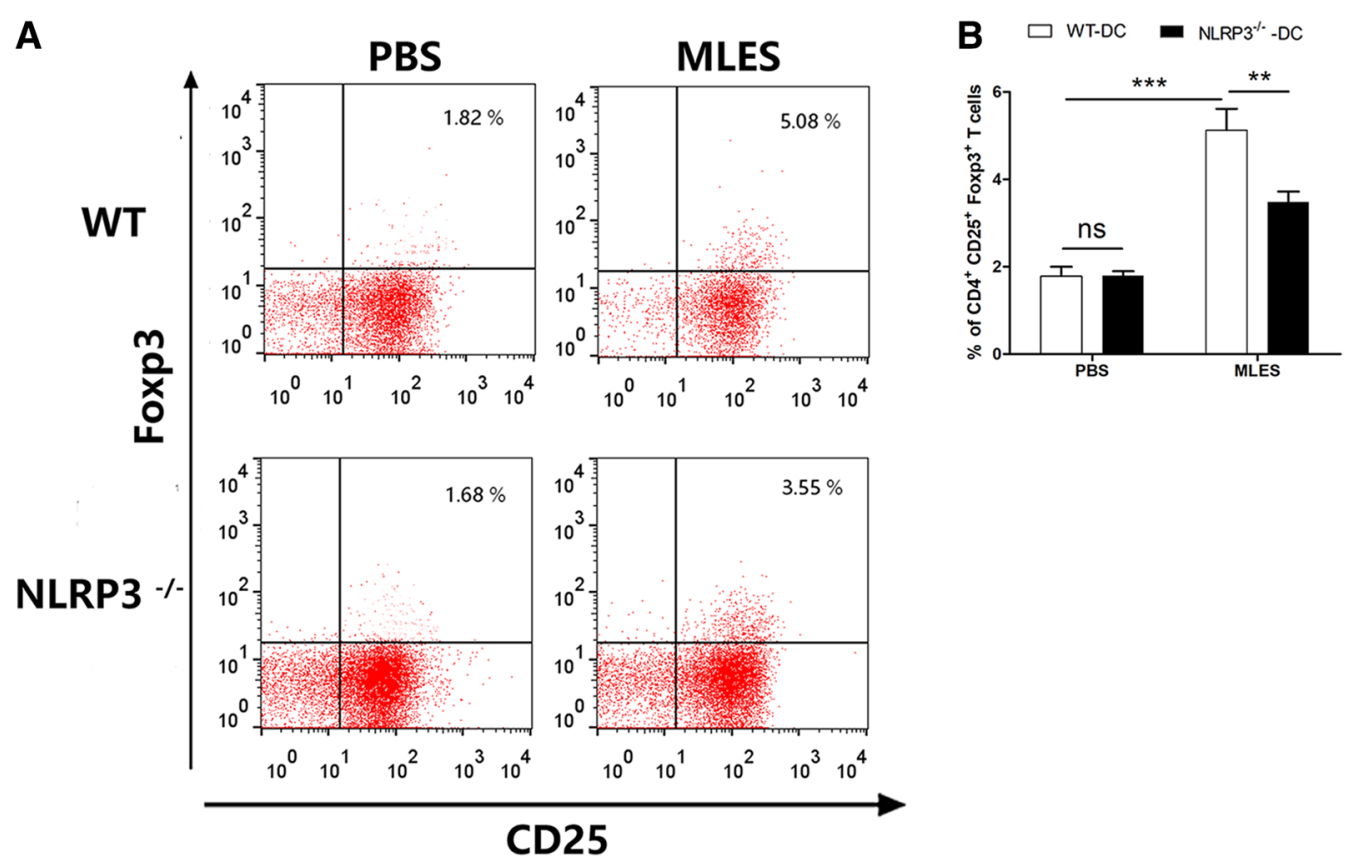

Figure 7 Population of Treg cells by MLES-treated DCs in vitro. A Treg populations induced by MLES -treated DCs were measured. $\mathrm{CD} 4^{+} \mathrm{CD} 25^{+}$Foxp $3^{+} T$ cells were determined by flow cytometry, and $\mathbf{B}$ the summarized results are presented as the mean $\pm S D(n=6)$ of three different experiments. ${ }^{*} p<0.05$, ${ }^{* *} p<0.01$, and ${ }^{* *} p<0.001$ as indicated by the line (one-way ANOVA with Tukey's post-test). The figures are representative of three independent experiments.

with MLESs strongly contributes to the induction of Th2 and Treg responses.

Taken together, these findings demonstrate that $\mathrm{NLRP}^{-1-}$ mice are more susceptible to T. spiralis infection and present enhanced Th2 and Treg responses by modulating the DC phenotype via NLRP3. We identified for the first time the involvement of NLRP3 in host defences against $T$. spiralis. NLRP3 therefore represents an important target for the control of $T$. spiralis infection.

\section{Abbreviations}

ANOVA: one-way analysis of variance; ASC: apoptosis-associated speck-like protein containing a CARD; CD: cluster of differentiation; DC: dendritic cell; dpi: days post infection; IL: interleukin; IFN: interferon; IgE: immunoglobulin E; i.p.: intraperitoneally; MLES: muscle larvae excretory-secretory products; NLR: nodlike receptor; NLRP3: NLR family, pyrin domain containing 3; OVA: ovalbumin; PBS: phosphate-buffered saline; PPRs: pattern recognition receptors; TCR: T cell receptor; TGF: transforming growth factor; Th2: Thelper 2; TLR: toll-like receptor; Treg: regulatory $\mathrm{T}$ cells.

\section{Acknowledgements}

C57BL/6J NLRP3 ${ }^{-1-}$, Caspase $1 / 11^{-/-}$, and $\mathrm{ASC}^{-/-}$mice were kindly provided by Dr. Feng Shao (National Institute of Biological Sciences, Beijing, China). We thank Prof. Xuejin Su, Key Laboratory of Pathobiology, Ministry of Education, for providing us with technical assistance. Our thanks are also extended to express our gratitude to all the people who made this work.

\section{Authors' contributions}

$X J$ and $X B$ carried out the literature search and drafted the first version of the manuscript. XJ, XB and JD were responsible for designing and analyzed the data. XJ, JD, and YY performed the experiments and assisted on the sample collections. ML, XL, HS, BP, BF revised the review. All authors read and approved the final manuscript.

\section{Funding}

This study was supported by the National Natural Science Foundation of China (31520103916, 31872467), The National Key Research and Development Program of China (2017YFD0501300); Guangdong Innovative and Entrepreneurial Research Team Program (2014ZT05S123); Jilin Provincial Science and Technology Development Project (20180520042JH); and Program for JLU Science and Technology Innovative Research Team.

\section{Availability of data and materials}

The datasets supporting the conclusions of this article are included within the article.

\section{Ethics approval and consent to participate}

All experiments in this study were conducted according to the regulations of the Administration of Affairs Concerning Experimental Animals in China. The procedure of animal experiments was approved by the Institutional Animal Care and Use Committee of Jilin University (No. 20170318).

\section{Competing interests}

The authors declare that they have no competing interests.

\section{Author details}

${ }^{1}$ Key Laboratory of Zoonosis Research, Ministry of Education, Institute of Zoonosis, College of Veterinary Medicine, Jilin University, Changchun 130062, China. ${ }^{2}$ Mucosal Immunology and Biology Research Center, Massachusetts General Hospital, Charlestown, MA, USA. ${ }^{3}$ Lanzhou Veterinary Research Institute, Chinese Academy of Agricultural Sciences, Lanzhou, China. ${ }^{4}$ JRU BIPAR, ANSES, École Nationale Vétérinaire d'Alfort, INRA, Université ParisEst, Animal Health Laboratory, Maisons-Alfort, France. ${ }^{5}$ Jiangsu Co-innovation 
Center for Prevention and Control of Important Animal Infectious Diseases and Zoonoses, Yangzhou, Jiangsu, People's Republic of China.

\section{Received: 9 July 2020 Accepted: 10 August 2020} Published online: 27 August 2020

\section{References}

1. Robertson $L J$ (2018) Parasites in food: from a neglected position to an emerging issue. Adv Food Nutr Res 86:71-113

2. Della Bella C, Benagiano M, De Gennaro M, Gomez-Morales M, Ludovisi A, Elios S, Luchi S, Pozio E, D’Elios MM, Bruschi F (2017) T-cell clones in human trichinellosis: evidence for a mixed Th1/Th2 response. Parasite Immunol 39:e12412

3. Finkelman FD, Shea-Donohue T, Morris SC, Gildea L, Strait R, Madden KB, Schopf L, Urban JF Jr (2004) Interleukin-4- and interleukin-13-mediated host protection against intestinal nematode parasites. Immunol Rev 201:139-155

4. Beiting DP, Gagliardo LF, Hesse M, Bliss SK, Meskill D, Appleton JA (2007) Coordinated control of immunity to muscle stage Trichinella spiralis by IL-10, regulatory T cells, and TGF-beta. J Immunol 178:1039-1047

5. Isabel F, Joana L, Joao DM, Ana S, Bruno Miguel N, Maria Teresa C (2017) Inflammasome in dendritic cells immunobiology: implications to diseases and therapeutic strategies. Curr Drug Targets 18:1003-1018

6. Sofronic-Milosavljevic L, llic N, Pinelli E, Gruden-Movsesijan A (2015) Secretory products of trichinella spiralis muscle larvae and immunomodulation: implication for autoimmune diseases, allergies and malignancies. J Immunol Res 2015:523875

7. Ilic N, Gruden-Movsesijan A, Cvetkovic J, Tomic S, Vucevic DB, Aranzamendi C, Colic M, Pinelli E, Sofronic-Milosavljevic L (2018) Trichinella spiralis excretory-secretory products induce tolerogenic properties in human dendritic cells via toll-like receptors 2 and 4. Front Immunol 9:11

8. Evavold CL, Kagan JC (2018) How inflammasomes inform adaptive immunity. J Mol Biol 430:217-237

9. Martinon F, Burns K, Tschopp J (2002) The inflammasome: a molecular platform triggering activation of inflammatory caspases and processing of prolL-beta. Mol Cell 10:417-426

10. Davis BK, Wen H, Ting JP (2011) The inflammasome NLRs in immunity, inflammation, and associated diseases. Annu Rev Immunol 29:707-735

11. Moreira-Souza ACA, Almeida-da-Silva CLC, Rangel TP, Rocha GDC, Bellio M, Zamboni DS, Vommaro RC, Coutinho-Silva R (2017) The P2X7 receptor mediates Toxoplasma gondii control in macrophages through canonical NLRP3 inflammasome activation and reactive oxygen species production. Front Immunol 8:1257

12. Lima-Junior DS, Costa DL, Carregaro V, Cunha LD, Silva AL, Mineo TW, Gutierrez FR, Bellio M, Bortoluci KR, Flavell RA, Bozza MT, Silva JS, Zamboni DS (2013) Inflammasome-derived IL-1 beta production induces nitric oxide-mediated resistance to Leishmania. Nat Med 19:909-915

13. Jiang P, Wang ZQ, Cui J, Zhang X (2012) Comparison of artificial digestion and Baermann's methods for detection of Trichinella spiralis pre-encapsulated larvae in muscles with low-level infections. Foodborne Pathog Dis 9:27-31

14. Wang L, Cui J, Hu DD, Liu RD, Wang ZQ (2014) Identification of early diagnostic antigens from major excretory-secretory proteins of Trichinella spiralis muscle larvae using immunoproteomics. Parasites Vectors 7:40

15. Schwarz H, Schmittner M, Duschl A, Horejs-Hoeck J (2014) Residual endotoxin contaminations in recombinant proteins are sufficient to activate human CD1c+ dendritic cells. PLoS One 9:e113840

16. Zhang R, Sun Q, Chen Y, Sun X, Gu Y, Zhao Z, Cheng Y, Zhao L, Huang J, Zhan B, Zhu X (2018) Ts-Hsp70 induces protective immunity against Trichinella spiralis infection in mouse by activating dendritic cells through TLR2 and TLR4. PLoS Neglect Trop Dis 12:e0006502-e0006502

17. Lutz MB, Kukutsch N, Ogilvie AL, Rossner S, Koch F, Romani N, Schuler G (1999) An advanced culture method for generating large quantities of highly pure dendritic cells from mouse bone marrow. J Immunol Methods 223:77-92

18. Jin X, Yang Y, Liu X, Shi H, Cai X, Luo X, Liu M, Bai X (2019) GlutathioneS-transferase of Trichinella spiralis regulates maturation and function of dendritic cells. Parasitology 146:1725-1732
19. Cvetkovic J, Sofronic-Milosavljevic L, Ilic N, Gnjatovic M, Nagano I, Gruden-Movsesijan A (2016) Immunomodulatory potential of particular Trichinella spiralis muscle larvae excretory-secretory components. Int J Parasitol 46:833-842

20. Hayward JA, Mathur A, Ngo C, Man SM (2018) Cytosolic recognition of microbes and pathogens: inflammasomes in action. Microbiol Mol Biol Rev. https://doi.org/10.1128/MMBR.00015-18

21. Clay GM, Sutterwala FS, Wilson ME (2014) NLR proteins and parasitic disease. Immunol Res 59:142-152

22. Goncalves VM, Matteucci KC, Buzzo CL, Miollo BH, Ferrante D, Torrecilhas AC, Rodrigues MM, Alvarez JM, Bortoluci KR (2013) NLRP3 controls Trypanosoma cruzi infection through a caspase-1-dependent IL-1R-independent NO production. PLoS Neglect Trop Dis 7:e2469

23. Gorfu G, Cirelli KM, Melo MB, Mayer-Barber K, Crown D, Koller BH, Masters S, Sher A, Leppla SH, Moayeri M, Saeij JP, Grigg ME (2014) Dual role for inflammasome sensors NLRP1 and NLRP3 in murine resistance to Toxoplasmagondii. mBio. 5:e01117

24. Tavares AH, Magalhaes KG, Almeida RD, Correa R, Burgel PH, Bocca AL (2013) NLRP3 inflammasome activation by Paracoccidioides brasiliensis. PLoS Neglect Trop Dis 7:e2595

25. Shio MT, Christian JG, Jung JY, Chang KP, Olivier M (2015) PKC/ROSMediated NLRP3 inflammasome activation is attenuated by leishmania zinc-metalloprotease during infection. PLoS Neglect Trop Dis 9:e0003868

26. Wang N, Bai X, Tang B, Yang Y, Wang X, Zhu H, Luo X, Yan H, Jia H, Liu M, Liu $X$ (2020) Primary characterization of the immune response in pigs infected with Trichinella spiralis. Vet Res 51:17

27. Everts B, Smits HH, Hokke CH, Yazdanbakhsh M (2010) Helminths and dendritic cells: sensing and regulating via pattern recognition receptors, Th2 and Treg responses. Eur J Immunol 40:1525-1537

28. MacDonald AS, Patton EA, La Flamme AC, Araujo MI, Huxtable CR, Bauman B, Pearce EJ (2002) Impaired Th2 development and increased mortality during Schistosoma mansoni infection in the absence of CD40/ CD154 interaction. J. Immunol. 168:4643-4649

29. Li T, Zehner M, He J, Prochnicki T, Horvath G, Latz E, Burgdorf S, Takeoka S (2019) NLRP3 inflammasome-activating arginine-based liposomes promote antigen presentations in dendritic cells. Int J Nanomed 14:3503-3516

30. McSorley HJ, Maizels RM (2012) Helminth infections and host immune regulation. Clin Microbiol Rev 25:585-608

31. Lu F, Lan Z, Xin Z, He C, Guo Z, Xia X, Hu T (2020) Emerging insights into molecular mechanisms underlying pyroptosis and functions of inflammasomes in diseases. J Cell Physiol 235:3207-3221

32. Besnard AG, Guillou N, Tschopp J, Erard F, Couillin I, Iwakura Y, Quesniaux $V$, Ryffel $B$, Togbe D (2011) NLRP3 inflammasome is required in murine asthma in the absence of aluminum adjuvant. Allergy 66:1047-1057

33. Helmby H, Grencis RK (2004) Interleukin 1 plays a major role in the development of Th2-mediated immunity. Eur J Immunol 34:3674-3681

34. Sawada M, Kawayama T, Imaoka H, Sakazaki Y, Oda H, Takenaka S, Kaku Y, Azuma K, Tajiri M, Edakuni N, Okamoto M, Kato S, Hoshino T (2013) IL-18 induces airway hyperresponsiveness and pulmonary inflammation via CD4+ T cell and IL-13. PLoS One 8:e54623

35. Jin X, Yang Y, Ding J, Liu X, Shi H, Luo X, Jia W, Cai X, Vallee I, Boireau P, Bai, Liu M (2020) Nod-like receptor pyrin domain containing 3 plays a key role in the development of Th2 cell-mediated host defenses against Trichinella spiralis infection. Vet Parasitol:109159

36. Koch KN, Hartung ML, Urban S, Kyburz A, Bahlmann AS, Lind J, Backert S, Taube C, Muller A (2015) Helicobacter urease-induced activation of the TLR2/NLRP3/IL-18 axis protects against asthma. J Clin Investig 125:3297-3302

37. Oertli M, Sundquist M, Hitzler I, Engler DB, Arnold IC, Reuter S, Maxeiner J, Hansson M, Taube C, Quiding-Jarbrink M, Muller A (2012) DC-derived IL-18 drives Treg differentiation, murine Helicobacter pylori-specific immune tolerance, and asthma protection. J Clin Investig 122:1082-1096

38. Xing Y, Cao R, Hu HM (2016) TLR and NLRP3 inflammasome-dependent innate immune responses to tumor-derived autophagosomes (DRibbles). Cell Death Dis 7:e2322-e2322

39. Pulendran B, Tang H, Manicassamy S (2010) Programming dendritic cells to induce $\mathrm{T}(\mathrm{H}) 2$ and tolerogenic responses. Nat Immunol 11:647-655

40. Lech M, Lorenz G, Kulkarni OP, Grosser MO, Stigrot N, Darisipudi MN, Gunthner R, Wintergerst MW, Anz D, Susanti HE, Anders HJ (2015) NLRP3 and ASC suppress lupus-like autoimmunity by driving the 
immunosuppressive effects of TGF-beta receptor signalling. Ann Rheum Dis 74:2224-2235

41. Ricci ND, Fiuza JA, Bueno LL, Cancado GG, Gazzinelli-Guimaraes PH, Martins VG, Matoso LF, de Miranda RR, Geiger SM, Correa-Oliveira R, Gazzinelli A, Bartholomeu DC, Fujiwara RT (2011) Induction of CD4(+) CD25(+)FOXP3(+) regulatory T cells during human hookworm infection modulates antigen-mediated lymphocyte proliferation. PLoS Neglect Trop Dis 5:e1383

42. Ilic N, Gruden-Movsesijan A, Sofronic-Milosavljevic L (2012) Trichinella spiralis: shaping the immune response. Immunol Res 52:111-119
43. Moulin V, Andris F, Thielemans K, Maliszewski C, Urbain J, Moser M (2000) $B$ lymphocytes regulate dendritic cell (DC) function in vivo: increased interleukin 12 production by DCs from B cell-deficient mice results in T helper cell type 1 deviation. J Exp Med 192:475-482

\section{Publisher's Note}

Springer Nature remains neutral with regard to jurisdictional claims in published maps and institutional affiliations.
Ready to submit your research? Choose BMC and benefit from:

- fast, convenient online submission

- thorough peer review by experienced researchers in your field

- rapid publication on acceptance

- support for research data, including large and complex data types

- gold Open Access which fosters wider collaboration and increased citations

- maximum visibility for your research: over $100 \mathrm{M}$ website views per year

At BMC, research is always in progress.

Learn more biomedcentral.com/submissions 